\title{
Quality of Local Rams Meat Given Fermented Cassava Peel-Based Feed Using Local Microorganisms
}

\author{
Dirja, Hamdan*, and N. Ginting \\ Animal Production Program Study, Faculty of Agriculture, Universitas Sumatera Utara, Padang \\ Bulan, Medan 20155, Indonesia. \\ *Correspondent author: hamdanspt@gmail.com
}

\begin{abstract}
This research aims to examine the provision of fermented cassava peel using local microorganisms on the quality of local rams' meat. This research was conducted at Mr. Praditya Rahardja farm, Jalan Bunga Rinte, Kecamatan Medan Tuntungan, Kota Medan, the Food Technology Laboratory of the Faculty of Agriculture and the Laboratory of Biochemistry/Chemistry Faculty of Mathematics and Natural Sciences, University of North Sumatra, using 12 local rams from December 2019 to March 2020. This research designed using a completely randomized design (CRD) with 4 treatments and 5 replications. The treatments were various levels of fermented cassava peel using local microorganisms consisted of P0: ration without the addition of fermented cassava peel using local microorganisms; P1: ration with the addition of $25 \%$ fermented cassava peel using local microorganisms; P2: ration with the addition of 50\% fermented cassava peel using local microorganisms and P3: ration with the addition of $75 \%$ fermented cassava peel using local microorganism. This research parameters were meat water content, meat protein content, meat fat content and meat shrinkage. The results showed that thelevel of concentrate gave a very significant difference $(\mathrm{P}<0,01)$ of protein content and meat fat content, but did not provide a significant difference of water content and cooking meat shrinkage.
\end{abstract}

Keywords: cassava peel, local microorganisms (MOL), meat quality, male local sheep.

Received [11 April 2020] | Revised [19 April 2020] |Accepted [23 April 2020]

\section{Introduction}

Sheep is a livestock that is mostly raised by the people of Indonesia, especially in rural areas. The role of sheep for farmers is quite large, because as one of the sources of family income and for future savings. Livestock is one of the producers of meat that is spread throughout Indonesia. Meat is a food from livestock that is needed to meet human nutritional needs, especially as animal protein needed to maintain body tissues, replace or repair damaged body tissue.

The quality of meat which is the final result of livestock cannot be separated from the quality of feed provided. Feed that has a good nutritional content will certainly produce quality meat. Feed is one of the most important factors in the livestock business.

when viewed in terms of cost, feed prices can reach $70 \%$ of the total production cost. this becomes one of the problems for farmers. One of the results of agricultural waste that can still be used as feed ingredients for sheep is cassavapeel. Cassava peel is the result of peeled waste processing 
chips, tapioca, cassava, tape, and other cassava-based snacks that are still still has nutritional content. [1] noted that in North Sumatra there were 1,619,495 tons of cassava production in 2015.

Besides that, cassava peel also has antinutrient content which is cyanide of $150-360 \mathrm{mg} / \mathrm{kg}$, if given directly to livestock, it can cause death. Fermentation process is needed as a microbial starter to be propagated in the substrate. Local microorganisms (MOL) can be used as a starter in fermentation technology. Based on [2] states that fermentation using local microorganisms on cassava peel is an increase in the nutritional content of cassava peels.

\section{Method}

The study was carried out at Mr. Praditya Rahardja's farm, Jalan Bunga Rinte, Tuntung District, Medan City. This research lasted for 3 months, starting in December 2019 until March 2020. And then continued at the Laboratory of Food Technology, Faculty of Agriculture and Biochemistry Laboratory, Faculty of Mathematics and Natural Sciences, University of North Sumatra. Equipment that will be used are 20 individual units of 1x1 m size, 40 units of feed and drink units, mortars for grinding meat, Kjhehldahl tubes for testing protein content, waterbaths for boiling meat, ovens for viewing the total water content of meatand a experimental thermometer for testing meat tenderness, $\mathrm{NaOH}$, Aquades, $\mathrm{HCL}, \mathrm{H} 2 \mathrm{SO} 4$ and $\mathrm{H} 2 \mathrm{O} 2.20$ local male sheep, drugs such as worm medicine (kalbazen), antibloat for bloating and vitamins. Clean water to meet the needs of drinking water given ad libitum, water to boil the meat.

Table 1. Composition of feed ingredients

\begin{tabular}{|c|c|c|c|c|}
\hline Composition (\%) & P0 & P1 & P2 & $\mathbf{P 3}$ \\
\hline Fermented Cassava peel & 0 & 25 & 50 & 75 \\
\hline Soybean meal & 10 & 10,50 & 13 & 17 \\
\hline Palm kernel & 14 & 14,50 & 11,50 & 2 \\
\hline Corn bran & 10 & 5,50 & 4,50 & 1 \\
\hline Rice bran & 28 & 20 & 7 & 0 \\
\hline Onggok & 33 & 19,50 & 9 & 0 \\
\hline Molasses & 3 & 3 & 3 & 3 \\
\hline Ultra-mineral & 1 & 1 & 1 & 1 \\
\hline Urea & 1 & 1 & 1 & 1 \\
\hline Total & 100 & 100 & 100 & 100 \\
\hline \multicolumn{5}{|c|}{ The content of nutrition ingredients material (\%) } \\
\hline Dry matter & 86,32 & 86,67 & 86,97 & 87,20 \\
\hline Crude protein & 15,25 & 15,22 & 15,22 & 15,20 \\
\hline Crude fiber & 6,04 & 7,82 & 8,83 & 9,31 \\
\hline Crude fat & 5,50 & 4,81 & 3,70 & 2,50 \\
\hline TDN & 74,28 & 74,22 & 74,15 & 74,08 \\
\hline
\end{tabular}

The study was conducted experimentally using a completely randomized design(CRD) 4 treatments and 5 replications. The treatments given are as follows:

P0: Cassava peel without fermentation in rations.

P1: $25 \%$ cassava peel fermented in rations. 
P2: $50 \%$ cassava peel fermented in rations.

P3: $75 \%$ cassava peel fermented in rations.

The parameters observed in this study included: Meat water content, protein level, fat level, and the shrinkage of cooked meat. The data obtained wereanalyzed based on analysis of variance. If there is a treatment effect, Duncan multiple area test will be conducted according to [3].

\section{Result and Discussion}

Table 2. Recapitulation of the local ram's meat quality (\%)

\begin{tabular}{lrrrr}
\hline Treatment & Water of meat & $\begin{array}{c}\text { Research parameters } \\
\text { protein level of meat }\end{array}$ & $\begin{array}{c}\text { Fat level of } \\
\text { meat }\end{array}$ & Meat shrinkage \\
\hline P0 & 75,89 & $22,09^{\mathrm{C}}$ & $14,40^{\mathrm{C}}$ & $40,03^{\mathrm{A}}$ \\
P1 & 75,31 & $22,16^{\mathrm{B}}$ & $16,77^{\mathrm{C}}$ & $36,23^{\mathrm{A}}$ \\
P2 & 75,79 & $23,50^{\mathrm{B}}$ & $19,07^{\mathrm{B}}$ & $41,06^{\mathrm{A}}$ \\
P3 & 76,35 & $25,89^{\mathrm{A}}$ & $22,30^{\mathrm{A}}$ & $38,66^{\mathrm{A}}$ \\
\hline
\end{tabular}

Note: Different superscripts in the same row and column show very significant differences $(\mathrm{P}$ $<0.01)$.

The same superscript in the same row and column shows no significant difference $(\mathrm{P}>0.05)$.

\subsection{Meat Water Content}

Fermented cassava peel-based feed using local microorganisms on rams showed no significant effect on water content. The local water content of rams in the treatment given fermented cassava peel feed using local microorganisms, where the lowest average results are in P1 of $75.31 \pm$ $1.89 \%, \mathrm{P} 2$ of $75.79 \pm 0.45 \%$ and $\mathrm{P} 0$ as a control of $75.89 \pm 1.36 \%$. The highest water content in the treatmentgiven the addition of fermented cassava peel using local microorganisms in the feed was found at $\mathrm{P} 3$ of $76.35 \pm 0.26 \%$.

This is because fermented cassava peels using local microorganisms have increased water content after fermentation which was previously $6.0 \%$ to $11.33 \%$ [2]. The average water content of the research results is still in the normal range.

[4] states that the local sheep meat water content in different calpastatin genotypes is $75.705 \pm$ $4.06 \%$, [5] reported that the water content of local male lamb that is maintained in rural is $75.13 \%$. Meat water content is also positively related to meat protein level, where the protein level is able to bind water content, so the greater the protein level in meat, the tendency of water content in meat is also higher.

\subsection{Meat Protein Level}

Fermented cassava peel-based feeding using local microorganisms has a very significant effect ( $\mathrm{P}<0.01)$ on the protein level of local rams' meat. Protein level in this study shows the average protein level of meat during the study, where the lowest average was found in the treatment $\mathrm{P} 0$ as 
control of $22.09 \pm 0.44 \%$. Protein level tends to increase in the treatment given additional fermented cassava peel using local microorganisms in the feed, namely P1 of $22.16 \pm 0.25 \%, \mathrm{P} 2$ of $23.50 \pm 0.57 \%$ and the highest level of meat protein found at $\mathrm{P} 3$ of $25,89 \pm 0.48 \%$.

With different levels of feed consumption will result in different protein levels, this is due to an increase or decrease in the amount of feed consumption relatedto the quality of available feed, which can lead to meat characteristics andquality. Meat protein level in this study is said to be high because it differs from the opinion of [6] that the composition of local sheep meat protein level given silage-based feed of vegetable waste amounted to $18.39 \%$ to $21.05 \%$. Furthermore, according to [7] reported that female sheep meat protein which was fattened in a feedlot and the level of concentrate giving was between protein levels of $16.35 \%$, to $18.84 \%$ and Sianturi [8] stated that the content of meat protein level in Garut sheep given sorghum-based feed is $19.11 \%$.

\subsection{Meat Fat Level}

Calculation of meat fat level in local sheep that were fed fermented cassava peel- based feed using local microorganisms was highly significant $(\mathrm{P}<0.01)$. Where the lowest mean is at $\mathrm{P} 0$ as a control of $14.40 \pm 1.05 \%$. Fat level tends to increasein the treatment given additional fermented cassava peel using local microorganisms in the feed, namely P1 of $16.77 \pm 0.41 \%$, P2 of $19.07 \pm$ $0.68 \%$ and the highest level of meat fat found in $\mathrm{P} 3$ of $22,30 \pm 2.1 \%$.

This study does not differ greatly from the results of research obtained by [9] states that fat in lamb meat is $22.4 \%$. This is supported by the results of research Ramada [10] which states that the fat level in lamb meat is $14.8 \%$. The level of meat fat in this study is said to be quite high, because it is different from [7] which states that the fat level in female lamb which fattened in a feedlot and the rate of administration of concentrate is different at $7.28 \%$. The difference in meat fat level is caused by the difference and the amount of concentrate consumed by sheep. This has led to the provision of feed containing higher concentrations will produce fatty meat, while providing low concentrations and high fiber and will produce low fat level [7].

\subsection{Meat Shrinkage}

Fermented cassava peel-based feeding using local microorganisms showed that the results of the effect were not significant on the content of shrinkage of cookedlocal lamb meat. Meat shrinkage of local rams in the treatment given fermented cassava peel feed using local microorganisms, where the highest average yield was in $\mathrm{P} 2$ was $41.06 \pm 5.75 \%, \mathrm{P} 0$ as a control was $40.03 \pm 1.55 \%$. Meat shrinkage decreased in the treatment given additional fermented cassava peel using local microorganisms found at $\mathrm{P} 3$ of $38.66 \pm 3.53 \%$ and $\mathrm{P} 1$ of $36.23 \pm 5.25 \%$. Meat shrinkage from the study shows that the category of quality is quite good and suitable for consumption. [11] states that the quality of normal shrinkage of cooked meat generally varies around $15-54 \%$. 
The results of this study did not differ greatly from the results obtained by Ramadhan [12] on local rams' meat with different growth rates that were kept semi-intensive on average by $34.93 \%$. [13] also reported that meat shrinkage wasfed with the addition of calcium soap from lemuru fish oil by $28.65 \%$ to $33.24 \%$.

[14] states that the cooked shrinkage of lamb meat which is given complete and forage feed with a different percentage is $31.26 \%$ to $34.50 \%$. According to [15] (2002) that the amount meat shrinkage was influenced by the amount of cellular membrane damage, the amount of water coming out of meat, protein degradation and the ability of meat to bind water.

\section{Conclusion}

The provision of fermented cassava peel using local microorganisms has a very significant effect ( $\mathrm{P}<0.01)$ on the quality content of local rams' meat in terms of protein content and fat content, but it does not have a significant effect $(\mathrm{P}>0.05)$ on the quality of local rams' meat in terms of water content and meat shrinkage.

\section{REFERENCES}

[1] Badan Pusat Statistik. 2018. Produksi Ubi Kayu Menurut Provinsi (ton) 19932015. (https://www.bps.go.id/linkTableDinamis/view/id/880. Diakses 1 November 2018).

[2] Siburian, Indra. Pengaruh Fermentasi Kulit Singkong (Manihot Esculenta Crantz) Menggunakan Mikroorganisme Lokal (Mol) Sebagai Pakan Terhadap Kandungan Nutrisi Dan Antinutrisi Asam Sianida. Medan: Peternakan USU. 2019.

[3] Astuti, M. Pengantar Ilmu Statistik Untuk Peternakan dan Kesehatan Hewan. Cetakan pertama. Bogor: Binasti Publisher.2007.

[4] Saputra, Dari. Sifat Fisik Dan Kimia Daging Domba Lokal Asal Unit Pendidikan Dan Penelitian Peternakan Jonggol (Up3j) Pada Genotipe Calpastatin Yang Berbeda. Fakultas peternakan IPB. 2012.

[5] Purbowati, E., C. I. Sutrisno, E. Baliarti, S. P. S. Budhi dan W. Lestariana. Komposisi Kimia Otot Longissimus dorsi dan Biceps femoris Domba Lokal Jantan yang Dipelihara di Pedesaan pada Bobot Potong yang Berbeda. Animal Production 8(1): 1 - 7.2006.

[6] Falahudin dan O. Imanudin. Kualitas Daging Domba Yang Diberi Pakan Silase Limbah Sayuran. Fakultas Pertanian: Universitas Majalengka. 2018.

[7] Rosyidi, D., Susilo, A., Muhbianto, R. Pengaruh Penambahan Limbah Udang Terfermentasi Aspergillus niger pada Pakan Terhadap Kualitas Fisik Daging Ayam Broiler. Jurnal Ilmu dan Teknologi Hasil Ternak, Februari 2009. Hal 1-10 Vol. 4, No. 1. ISSN: 1978 - 0303.

[8] Sianturi, S. J. Kualitas Fisik, Kimia dan Histologi Daging Kambing Kacang dan Domba Garut yang Diberikan Pakan Berbasis Sorgum. Tesis. Bogor: Sekolah Pascasarjana Institut Pertanian Bogor. 2015. 
[9] Frandson, R. D. Anatomi dan Fisiologi Ternak. 4th Ed. Terjemahan: B. Srigandono dan Koen Praseno. Yogyakarta: Gadjah Mada University Press. 1992.

[10] Ramada, A. S. Daging Kambing atau Daging Domba? http://www.saungdomba.com/artikeldomba-garut/101-daging- kambing-atau-daging-domba. [9 -Desember 2011].

[11] Soeparno. Ilmu dan Teknologi Daging Cetakan Keempat. Yogyakarta: Gadjah Mada University Press. 2005.

[12] Ramadhan, F. Kualitas Daging Domba Lokal Jantan dengan Kecepatan Tumbuh Berbeda yang Dipelihara Secara Semi Intensif. Skripsi. Bogor: Fakultas Peternakan, Institut Pertanian Bogor. 2010.

[13] Sudarman, M. Muttakin dan H. Nuraini. Penambahan Sabun-Kalsium Dari Minyak Ikan Lemuru Dalam Ransum: 2. Pengaruhnya Terhadap Sifat Kimia dan Fisik Daging Domba. Fakultas Peternakan IPB. 2008.

[14] Riyadi, S. Sifat Fisik dan Asam Lemak Daging Domba yang Diberi Pakan Ransum Komplit dan Hijauan dengan Persentase yang Berbeda. Skripsi. Bogor: Fakultas Peternakan, Institut Pertanian Bogor. 2008.

[15] Shanks, B. C., D. M. Wulf, \& R. J. Maddock. Technical note: The Effect of Freezing On Warner Blatzer Shear Force Value Of Longissimus Steaks Across Several Postmortem Aging Periods. J. Anim. Sci. 80:2122-2125. 2002. 